\title{
Review \\ Long-term sustainability in the management of acid mine drainage wastewaters - development of the Rhodes BioSURE Process
}

\author{
Peter Rose* \\ Rhodes University, PO Box 480, Grahamstown, 6140, South Africa
}

\begin{abstract}
The decanting of flooded gold mines threatens water supply on the Witwatersrand, South Africa, one of the most intensively mined areas in the world. Large volumes of acid mine drainage wastewaters will require treatment here for decades and possibly centuries. Appropriate treatment technology needs to meet technical, financial, environmental and social sustainable development criteria, with the costs of long-term treatment providing the initial decision gateway. This review details a bioprocess development in which the use of sewage sludge as the electron donor/carbon source for microbial sulphate reduction, and the wastewater treatment public utility as the operator, was investigated in meeting these requirements. A programme is reviewed that led from fundamental studies in microbial ecology, enzymology and mathematical process modelling, through pilot plant studies, to the construction and operation of a full-scale plant treating $10 \mathrm{M} \ell$ mine water/day. It was shown, in what became known as the Rhodes BioSURE Process, that with careful regulation of the mine water and the sewage sludge dosing flow rates, sulphate levels could be reliably reduced to below $100 \mathrm{mg} / \ell$, at hydraulic retention times as low as $12 \mathrm{~h}$. Ancillary metal and sulphide removal unit operations are described, as well as investigations into socially sustainable use of treated mine waters.
\end{abstract}

Keywords: acid mine drainage, mine wastewater treatment, sewage sludge, sulphate removal, metal removal

\section{INTRODUCTION}

The environmental impacts of acid mine drainage (AMD) wastewaters have been the subject of intensive investigation over many years (Lottermoser, 2010), and the processes giving rise to its formation are now well-described (Blowes et al., 2003; Johnson, 2003). A considerable research effort in process development has focused on the treatment and mitigation of the AMD problem and both physico-chemical and biological processes have been applied in active and passive treatment operations (Johnson and Hallberg, 2005; Inter-Ministerial Committee, 2010).

While the hydrogeological modelling of AMD formation and discharge, following mine closure, has had considerable predictive success (Scott, 1995; Hodgson et al., 2001; Lin and Hanson, 2010), quantifying the time period over which flows of contaminated water may be anticipated has been less secure and may range from decades to many centuries (Younger, 1997). Roman mines in Britain and Bronze Age workings in Spain still actively generate AMD (Leblanc et al., 2000; Van Geen et al., 1997), and contamination of rivers by coal mines has been commonly reported 50-100 years after closure (Bell et al., 2001).

South Africa represents a paradigm case where the AMD threat to the public water system has reached acute levels in recent years (Naiker, 2003; Ewart, 2011; McCarthy, 2011; Tandlich, 2012). The water-scarce Witwatersrand region, which accounted for more than $10 \%$ of the economic activity of the entire African continent, is one of the largest human

\footnotetext{
To whom all correspondence should be addressed.

+27 82 801-1353; e-mail: p.rose@ru.ac.za

Received 2 October 2012; accepted in revised form 14 August 2013.
}

settlements in the Southern Hemisphere not located on a river (Turton, 2004). It has also been one of the most intensively mined areas in the world, with 37 million $\mathrm{kg}$ fine gold extracted (and 6 billion tons of ore milled) since the 1880s. This represents over $3 \%$ of estimated total global gold recovery since prehistoric times (Hartnady, 2009). Since gold production peaked at 1 million tons fine gold/year in the early 1970s, the industry here has been in decline, with the problems of mine closure leaving an increasing legacy of social, financial and particularly environmental consequences requiring urgent management. Given abandoned and orphan mines (Field, 2003), these problems have increasingly passed to the responsibility of the state and thus to the wider community (Inter-Ministerial Committee, 2010; Ewart, 2011).

With the termination of mine dewatering and pump-andtreat operations, as functions of the active mining enterprise, groundwater levels have been rising in the East, Central and West Rand Basins along the Witwatersrand (McCarthy, 2011). Hydrogeological modelling of this situation since the mid1990 s has predicted the time to reach decant status, the quantity and quality of waters that would decant once the filling of the mines was completed, and total volumes of AMD requiring treatment in this region, which may exceed several hundred Ml/day (Scott, 1995; Tutu et al., 2008; McCarthy, 2010). The potentially long-term nature of the problem has focused interest on the technical and financial sustainability of treatment operations able to deal with the AMD problem over extended periods of time, and this has in turn led to investigation of the advantages of biological compared to physico-chemical treatment technologies (Van der Merwe and Lea, 2003; InterMinisterial Committee, 2010).

Neba (2006) investigated the use of formal decision-support tools required to achieve an integration of environmental, economic and social factors in sustainable technology choice in the 


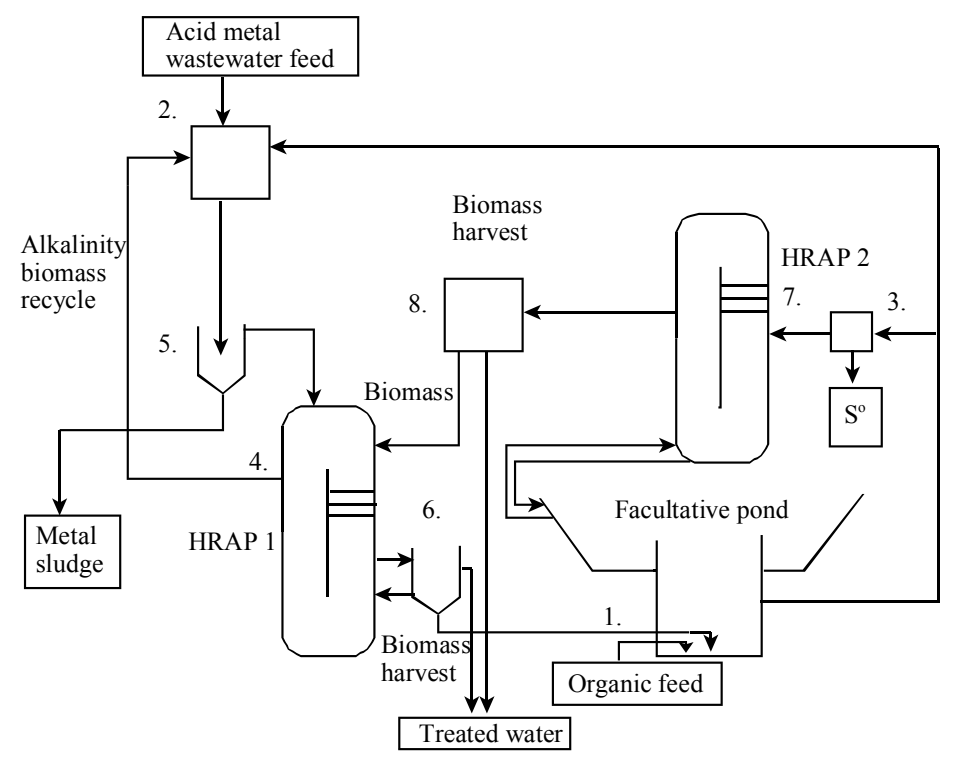

Figure 1

Flow diagram of the individual unit operations of the Integrated Algal Sulphate Reducing Ponding Process for Acid Metal Wastewater Treatment (ASPAM). Organic feed enters at $1=$ Facultative pond with anaerobic upflow digester compartment. Feed water enters at $2=$ Inlet and metal precipitation unit. Sulphide is recycled to metal precipitation unit from $3=$ sulphide recycle and sulphur recovery unit. Alkalinity and algal biomass generated in High Rate Algal Pond (HRAP)1 recirculated via 4. $5=$ Metal sludge settler $6=$ Algal biomass settler; 7 = High Rate Algal Pond (HRAP)2 for capping the Facultative Pond and seeding HRAP 1 with fresh biomass; $8=$ Algal biomass harvester (Rose et al., 2002).

mine wastewater treatment field. In a survey of decision makers in the minewater field, he found that these tools were lacking and that decision making was generally informally based. Seghezzo (2004) noted that short-term economic interests often propel technological innovations that would be generally construed as 'meaningless or even negative' within the requirements of sustainable development thinking.

It is against this background that an environmental biotechnology research programme is reviewed here which attempted a specific focus on the broader sustainability requirements of the AMD treatment operation. This led to the development of what became known as the Rhodes BioSURE Process and finally to its successful implementation in a $10 \mathrm{M} /$ day full-scale treatment plant. The sustainability rationale underpinning this development has been described by Neba et al. (2007) and was predicated on the use of readily-available organic wastes, such as sewage sludge, as the electron donor/ carbon source for the biological sulphate reduction reaction, the core unit operation in the technology. The location of the treatment function in the hands of the public utility operator relates to these organisations being in the long-term business of sewering and treating large volumes of wastewaters on a continuous daily basis, and for whom the co-disposal of sewage sludges, and possibly other organic wastes, provides a potential operational cost benefit.

While this research programme, funded primarily by the South African Water Research Commission and the ERWAT Water Care Company, ran over a period of some 15 years, and has been widely published in journal papers, student theses, research reports and conference proceedings, most of which are available in the public domain, no attempt has yet been made to review this initiative and present the details of the AMD treatment outcomes in a readily accessible form. This review thus commences with an overview of the origins of the research programme and outlines fundamental studies undertaken in the mechanisms underpinning the sulphidogenic breakdown of complex carbon substrates and the mathematical modelling of sulphate-reducing anaerobic processes. This led, in turn, to the process design and reactor configuration studies on which the Rhodes BioSURE Process development was based and then to piloting and full-scale plant construction and operation.

\section{BACKGROUND}

Development of the Rhodes BioSURE Process commenced at Rhodes University, Grahamstown, South Africa, in the early 1990s, with observations of enhanced degradation of complex organic wastes in sulphate-reducing tannery ponds (Rose, 1992; Boshoff et al., 1996; Rose et al., 1996; Dunn, 1998). Breakdown of refractory substrates, such as collagen- and keratin-based compounds, was found to be enhanced in the presence of active sulphate reduction in these saline systems, and was associated with the removal of heavy metal contaminants which were precipitated as metal-sulphide complexes (Boshoff, 1999).

Dunn (1998) also investigated the growth and production of microalgae in tannery ponds, including mainly Arthrospira (Spirulina) and Dunaliella spp., and showed that photosynthetic primary production contributed to the high rates of sulphate reduction and energy flux observed within these ecosystems. Boshoff et al. (2004a,b) showed, in bioprocess reactor development studies, that both organic wastes from the tanning operation, as well as algal growth in tannery wastewater ponds, could be effectively used as electron donor/carbon sources to fuel the sulphate reduction reaction. These studies led to the development of a bioprocess for treating high-sulphate wastewaters, such as AMD, in which an upflow anaerobic digester reactor was located within earthwork ponds (Fig. 1) following the Oswald design for Advanced Integrated Wastewater Ponding Systems (Oswald, 1988). In the so-called ASPAM Process (Integrated Algal Sulphate Reducing Ponding Process for Acid Metal Wastewater Treatment), algal primary production provided the electron donor/carbon source for sulphate reduction. The alkaline, sulphide-enriched treated stream was recycled to precipitate heavy metals and neutralise the incoming AMD stream (Rose et al., 1998; 1999; 2002). Van Hille et al. (1999a,b) have demonstrated the use of algal-based sulphate reduction in metal removal operations in a number of other industrial applications.

While the self-contained nature of these algal pondingbased systems provided an attractive treatment option for low-volume flows of sulphate/sulphide-enriched effluents, by the mid-1990s modelling of the flooding and decanting of AMD streams, following increasing mine closures in the Witwatersrand basins, indicated that exceptionally large AMD 


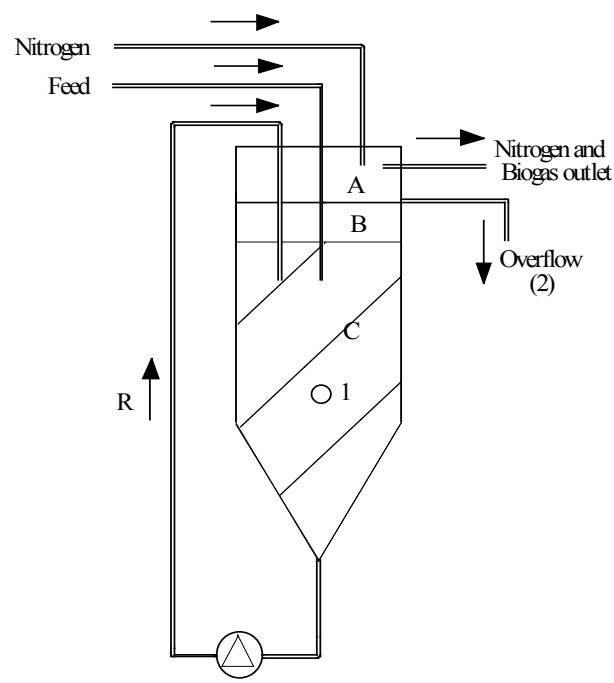

Figure 2

The laboratory-scale Recycling Sludge Bed Reactor used in the study in which influent particulate PSS was settled and recycled in simulation of sedimentation and upwelling conditions observed in tannery ponds. Supernatant liquid was discharged to the overflow. $A=$ headspace, $B=$ top zone, $C=$ bed, $R=$ recycle loop. 1 and $2=$ sampling ports. The headspace was flooded with nitrogen gas to maintain anaerobic conditions (Whittington-Jones, 2000).

volumes would soon require treatment (Scott, 1995). The question addressed to the research programme at that time was whether the biological systems investigated in the ASPAM development would perform comparably with physico-chemical AMD treatment operations in the large-volume flow treatment application. Apart from volume, cost and environmental sustainability of treatment over the long timeframes anticipated provided another of the principal questions to be addressed. These requirements focused attention on the potential of primary sewage sludge (PSS) to provide the electron donor/carbon source for sulphate reduction in the amounts required, and also on the wastewater treatment utility operator as a suitable entity to undertake the AMD treatment function.

Molepane (1999) and Molwantwa (2002) reported investigations into the use of PSS as an electron donor/carbon source in sulphate reduction reactions and Whittington-Jones (2000) developed the Recycling Sludge Bed Reactor (RSBR) as an experimental system for investigating PSS breakdown in a configuration comparable to the process of sedimentation and upwelling in which complex organic substrates were observed to be degraded in tannery ponds (Fig. 2). With hydrolysis as the rate-limiting step, he reported a 52\% yield of hydrolysis product from PSS in sulphate-reducing environments, an improvement of approximately $20 \%$ compared to previously-published results (Whittington-Jones et al. 2002).

In a number of fundamental enzymological studies, the enhancement of enzyme activity within sulphate-reducing PSS degrading systems has been reported by WhittingtonJones (2000), Enongene (2003a), Whittington-Jones et al (2006) and Watson et al. (2004). The effects of sulphate reduction on the activity of particular enzymes was demonstrated for carbohydrases (Whittington-Jones, 2000), proteases and phosphatases (Whitely et al. 2002a), lipases (Whitely et al., 2002b; 2003), sulphurylases (Pletschke et al., 2002) and $\beta$-glucosidase (Whitely et al., 2002c). Chauke (2002) investigated the molecular microbial ecology of PSS sulphate-reducing reactors and showed the presence of both

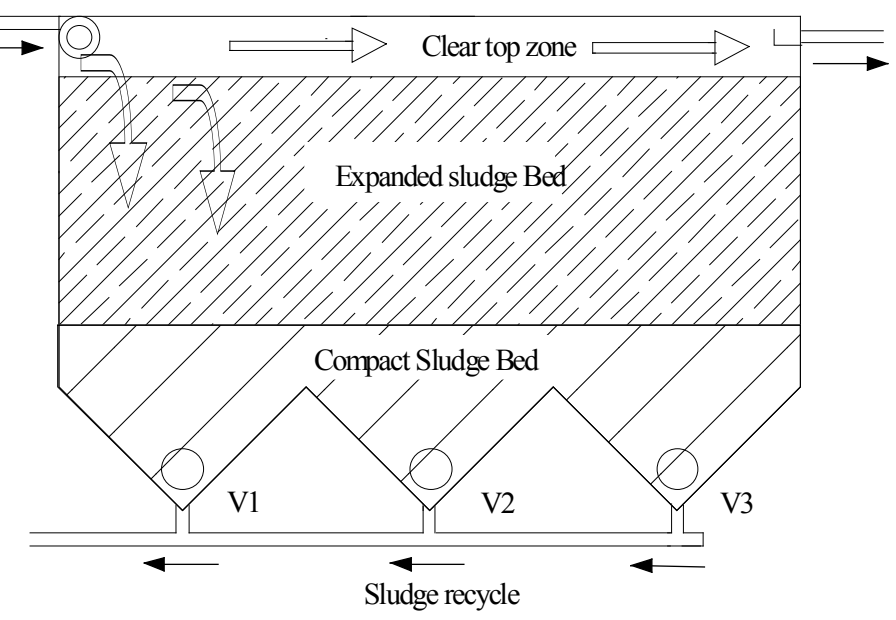

Figure 3

Cross-sectional view of the pilot-scale Recycling Sludge Bed Reactor showing the separation of soluble and suspended sewage fractions from settleable solids. The compacting sludge bed was withdrawn from the bottom of the reactor and recycled to blend again with the influent feed where the newly hydrolysed fractions then passed forward to the second stage of the treatment process (from Rose et al., 2004).

hydrolytic and sulphate-reducing prokaryotes. These studies appeared to provide a coherent theoretical account of how the enhancement of hydrolysis reactions might operate in the PSS sulphate-reducing environment.

\section{DEVELOPMENT OF THE RHODES BIOSURE PROCESS}

Corbett (2001) and Whittington-Jones et al. (2002) reported studies in which the RSBR concept was developed and scaled up through $2 \ell, 10 \ell, 3 \mathrm{~m}^{3}$ to $23 \mathrm{~m}^{3}$ reactor configurations. In these investigations, PSS particulates mixed with the influent AMD stream were settled onto an expanded sludge bed with the suspended and soluble PSS fractions passing forward to a second-stage sulphate reduction operation (Fig. 3). Hydrolytic, sulphidogenic and acidogenic anaerobic reaction conditions prevailed in the RSBR. In a series of reactor depth profile studies, Whittington-Jones et al. (2002) reported that enzyme activity in the RSBR sludge bed increased with depth, from $2100 \mathrm{nmol}$ to $12710 \mathrm{nmol}$ substrate converted, that both the filterable COD and suspended solids fractions rose towards the bottom of the RSBR and that floc size decreased. They showed that the effect of reduced floc size on the PSS hydrolysis reaction rate was significant $(P<0.001)$ and that shear and maceration effects introduced by the recycle pumping action added to the final fracturing of PSS flocs achieved. Sludge withdrawn from the bottom of the RSBR was recycled to blend back into the influent stream and with the newly degraded soluble and suspended PSS solids then being available to pass forward to a second-stage reactor.

In these studies a multi-compartment baffle reactor (Fig. 4) was investigated in a second-stage unit operation in which the soluble and suspended COD, derived from the hydrolysis and fracturing of the PSS flocs in the RSBR, provided a readily available electron donor/carbon source for the separate optimisation of the sulphate reduction reaction. The sludge bed in the upflow chambers of the Baffle Reactor, 


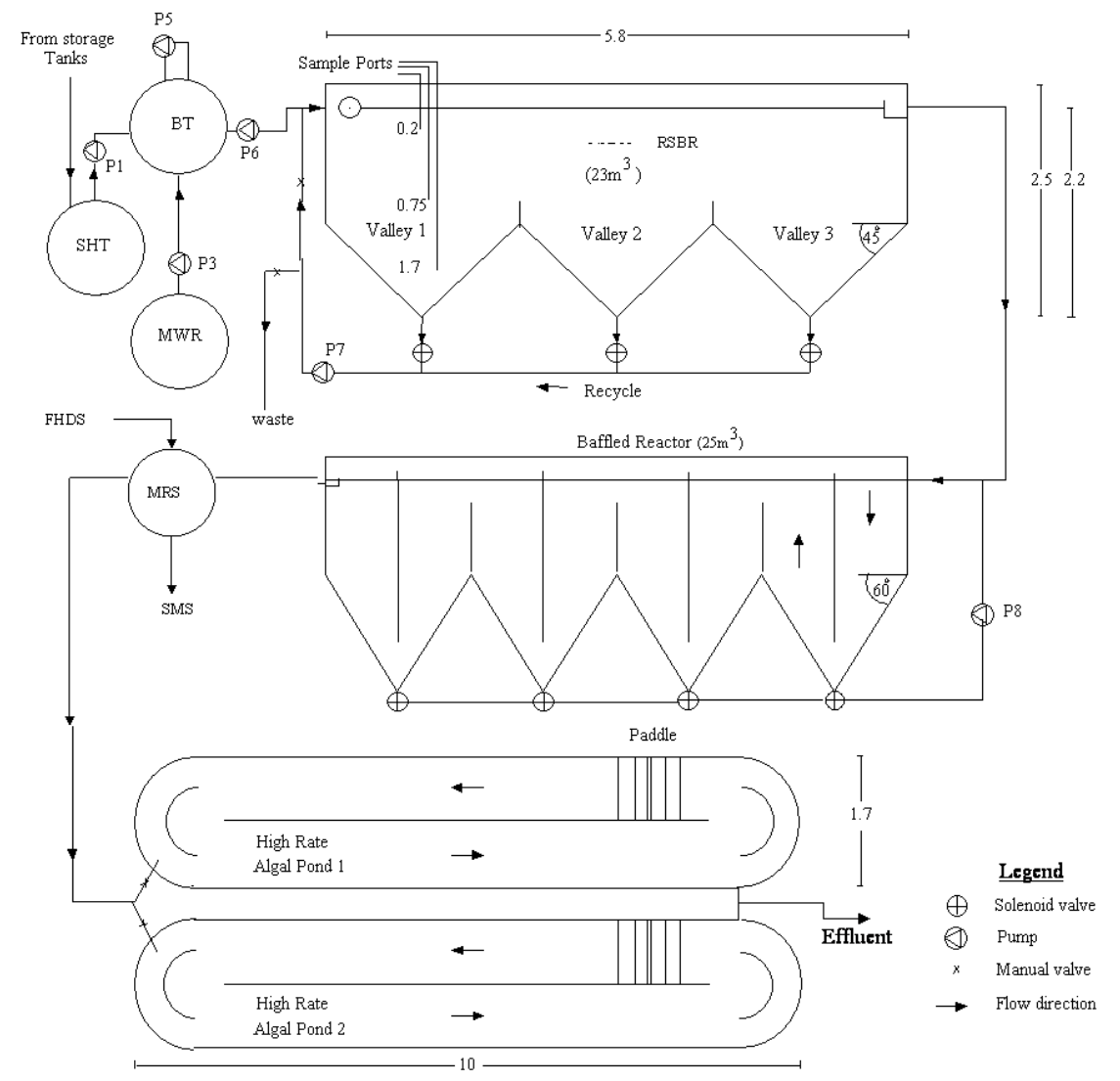

Figure 4

Process flow diagram of the pilot plant constructed at Grootvlei Gold Mine for the treatment of high-sulphate mine drainage wastewaters using sewage sludge as the electron donor/carbon source. $M W R=$ mine water reservoir; $S H T$ $=$ sludge holding tank $B T=$ blend tank; RSBR = Recycling Sludge Bed Reactor; FHDS = ferric iron high density sludge feed; $M R S=$ metal sludge settler; SMS = settled metal sludge; RSBR and Baffle Reactor in cross section, High Rate Algal pond in plan (from Rose et al. 2004). provided for the immobilisation of generally poorly-adhering sulphate-reducing prokaryotes (SRP), and also the entrapment of particulate COD. Complete anaerobic digestion was reported to dominate here with sulphate as the principal terminal electron acceptor. Control of the COD:sulphate ratio around 2:1 was found to be necessary to prevent a shift to methanogenic conditions, with gas production then causing disruption of the upflow sludge bed and washout of both the sludge bed and SRP biocatalyst (Corbett, 2001).

These findings were incorporated in the scale-up design of a pilot plant designed to treat $40 \mathrm{~m}^{3} /$ day AMD. Figure 4 shows the process flow path on which the subsequent scale-up studies of what came to be known as the Rhodes BioSURE Process were based (Rose and Hart, 1999a,b; 2001).

In addition to options for the removal of heavy metals in the AMD stream in the RSBR (Reactor 1) and the Baffle Reactor (Reactor 2), the removal of sulphur, and thus linearising the biological sulphur cycle, and the final polishing of the treated effluent have been reported (Rose et al., 2004). The pilot plant was constructed at the Grootvlei Gold Mine, in Springs on the Eastern Witwatersrand, where a lime high-density sludge (HDS) process was operated for metal removal from the 70-100 M /day AMD stream pumped from the mine. The neutralised, metal-free, high-sulphate effluent from the HDS process was used as the feed to the piloting operation (Corbett, 2001). The use of ferric iron/lime sludge from the HDS process was used for complexing sulphide generated in the biological sulphate reduction operation and its removal by subsequent precipitation as a metal sulphide complex (Enongene, 2003b). Sulphide removal by its partial oxidation to $S$ was also investigated in the development of a floating sulphur biofilm unit operation and has been reported by Molwantwa et al. (2007) and Molwantwa (2008).

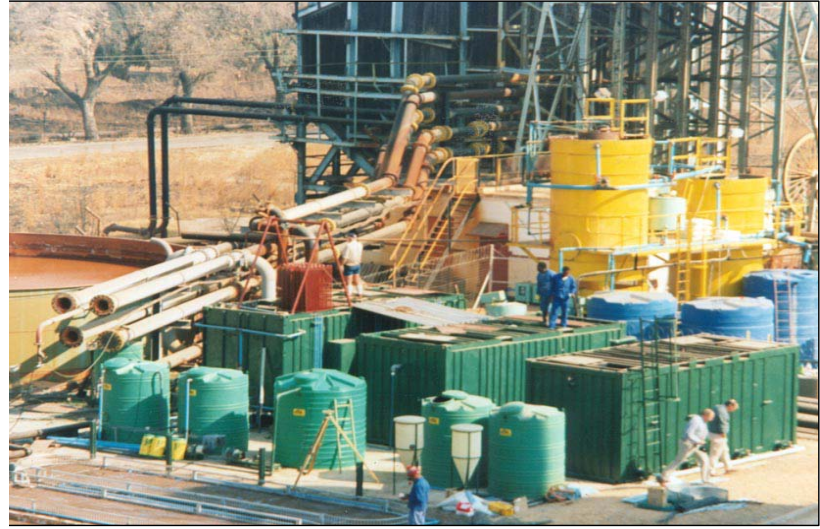

Figure 5

Photograph of the Rhodes BioSURE Process pilot plant under construction at the No.3 Shaft, Grootvlei Gold Mine, Springs, Ekurhuleni, Eastern Witwatersrand (from Rose et al., 2004)

Although this process has been scaled-up and evaluated elsewhere in linearising sulphur removal from AMD in passive treatment operations (Mack et al., 2009; Van Hille et al., 2011), it was not further applied in the studies reviewed here. The option for final polishing of the treated mine water in algal ponds, still available at many older sewage works, was also investigated and the use of high-rate algal ponds was evaluated in the pilot study (Corbett, 2001).

Figure 5 shows the pilot plant constructed at the No. 3 Shaft, Grootvlei Gold Mine, and operated for a period of 18 months. This plant was designed for the treatment of $40 \mathrm{~m}^{3} / \mathrm{day}$ AMD with sulphate loads varying between $1200 \mathrm{mg} / \ell$ and $2000 \mathrm{mg} / \ell$, and averaging around $1500 \mathrm{mg} / \ell$. PSS was supplied 

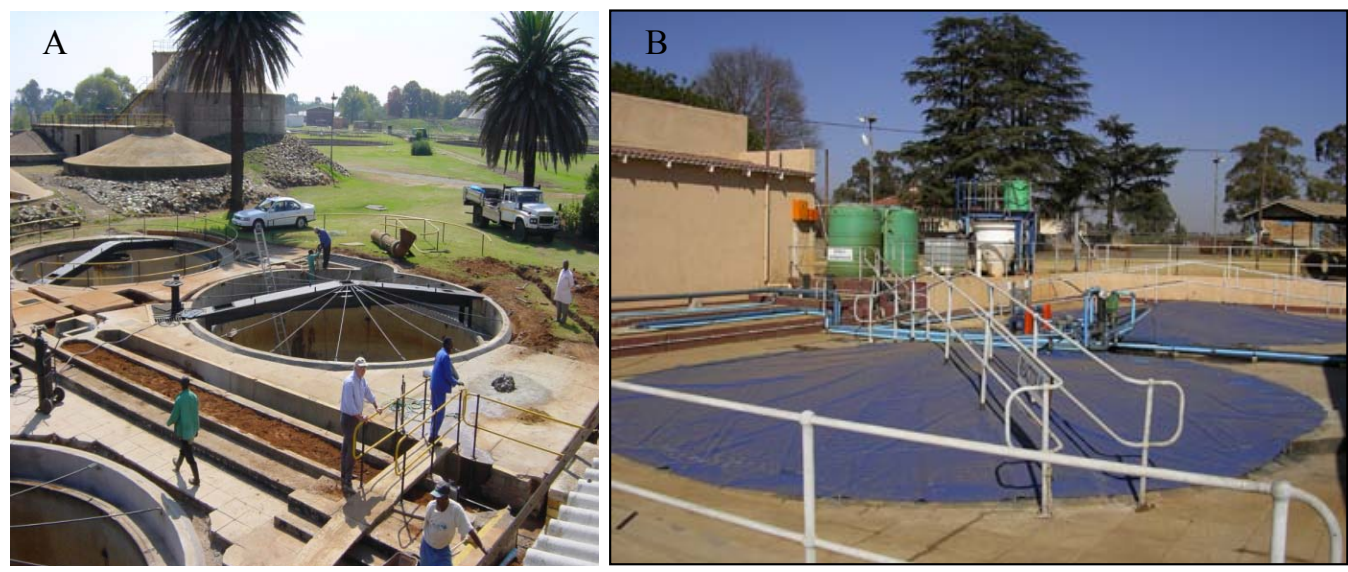

Figure 6

Photograph of the Dortmund tanks that were converted into reactor vessels in the technicalscale plant constructed at Ancor Works, Springs.

(A) reactor under construction (B) completed reactor sealed to prevent escape of sulphide gas and

to maintain anaerobic operating conditions (from

Rose et al., 2004)

by the ERWAT Water Care Company from the nearby Ancor sewage treatment works. The relationship between COD and sulphate in the process feed, maintained by the blending of sewage sludge and HDS-treated mine water, was shown to be critical to process performance. The COD:sulphate ratio was evaluated over a range from $0.5: 1$ to $4: 1$ and showed an optimum at 2:1. In these studies the sulphate load was reduced to an average of $225-300 \mathrm{mg} / \ell$ over the period in which the plant was operated (Rose et al., 2004).

\section{TECHNICAL-SCALE PILOTING}

The promising demonstration of sewage sludge as an electron donor/carbon source for sulphate removal from AMD wastewaters, in the pilot plant study at the Grootvlei Gold Mine, led to a decision to proceed to a technical-scale evaluation of the process (Neba, 2006; Neba et al., 2007). The construction of a plant sized to treat $1.6 \mathrm{Ml} /$ day was undertaken at the nearby Ancor sewage treatment works. A $2.4 \mathrm{~km}$ pipeline was constructed to supply pre-treated mine water from the Grootvlei Gold Mine HDS plant to the Ancor site where PSS supply was readily available for the study. Existing Dortmund-type clarifiers were reconfigured as the reactor vessels in these studies (Fig. 6).

An evaluation of a number of reactor operating configurations was undertaken in preliminary scale-up studies using the Dortmund tanks as reactors; Neba (2006) showed that there was no obvious advantage in separating the hydrolysis and sulphate reduction reactions in separate unit operations. Laboratory studies confirming the successful operation of the upflow anaerobic sludge bed (UASB) reactor configuration in sewage-based sulphate reduction were reported by Neba et al. (2007) and Ristow et al. (2009), and showed that the recycling sludge bed (observed in the RSBR) and the upflow digester operation (observed in the Baffle Reactor) could be conveniently incorporated into a single reactor unit operation which they termed the upflow RSBR (URSBR). The final reactor configuration and process flow path used in the technical-scale piloting studies is shown in Fig. 7.

Neba et al. (2007) reported a 418 day study of steady-state reactor operation of the process in the single reactor configuration, and a mean sulphate removal of $87 \%$ was demonstrated for the mine water feed in which the average sulphate load was $1300 \mathrm{mg} / \ell$ over this period. A COD:sulphate ratio of 2:1 was again found to provide the optimum feed rate to the reactor, with levels below that resulting in feed-limiting conditions. Above the 2:1 feed ratio the process tended towards

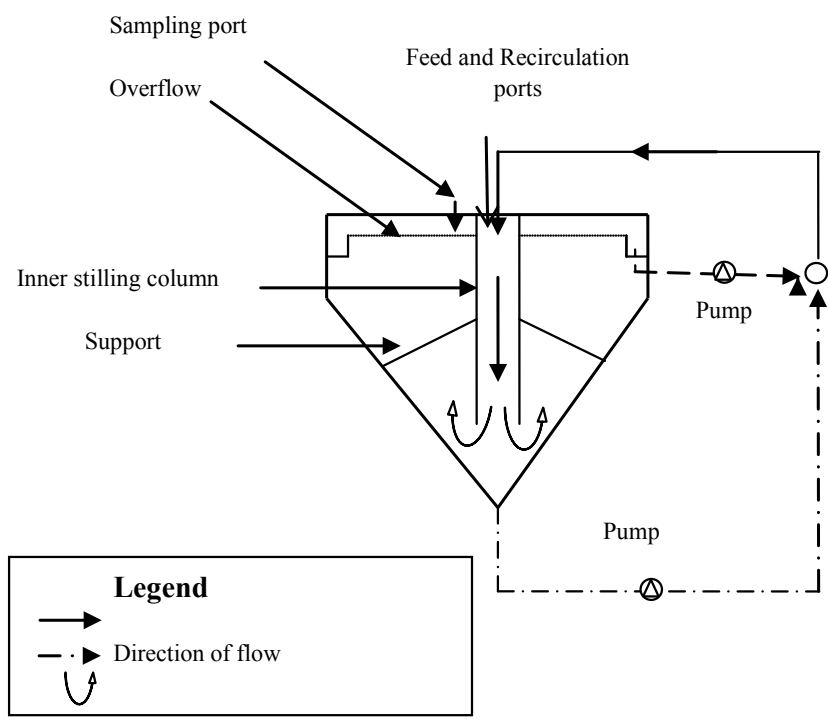

Figure 7

Schematic illustration of a Dortmund-type tank reconfigured as the reactor vessel in the technical-scale evaluation of the Rhodes BioSURE Process. In this design both recycling sludge bed and upflow operating configurations were incorporated into the same reactor vessel (Neba, 2006)

methanogenic operation, with gas production causing disruption of the sludge bed. The divergence observed from a theoretical COD:sulphate ratio of 0.7:1 is likely due to the nonbiodegradable organic fraction in sewage sludges.

This study showed that, with careful regulation of the mine water flow rate and the PSS dosing rate, sulphate could be reliably removed to below $100 \mathrm{mg} / \ell$ at hydraulic retention times as low as $12 \mathrm{~h}$.

\section{KINETIC-BASED PROCESS MODELLING}

Positive outcomes in the pilot and technical-scale studies on the Rhodes BioSURE Process, and a decision to investigate the development of a full-scale demonstration plant, led to the research and development of a kinetic-based integrated biological, physical and chemical process model for systems utilising PSS as the feed source for sulphate reduction (Ristow, 1999; 2004; Ristow et al., 2002; 2004; 2009). Methanogenic, acidogenic and sulphidogenic anaerobic digestion types were compared at varying retention times, feed concentrations and 


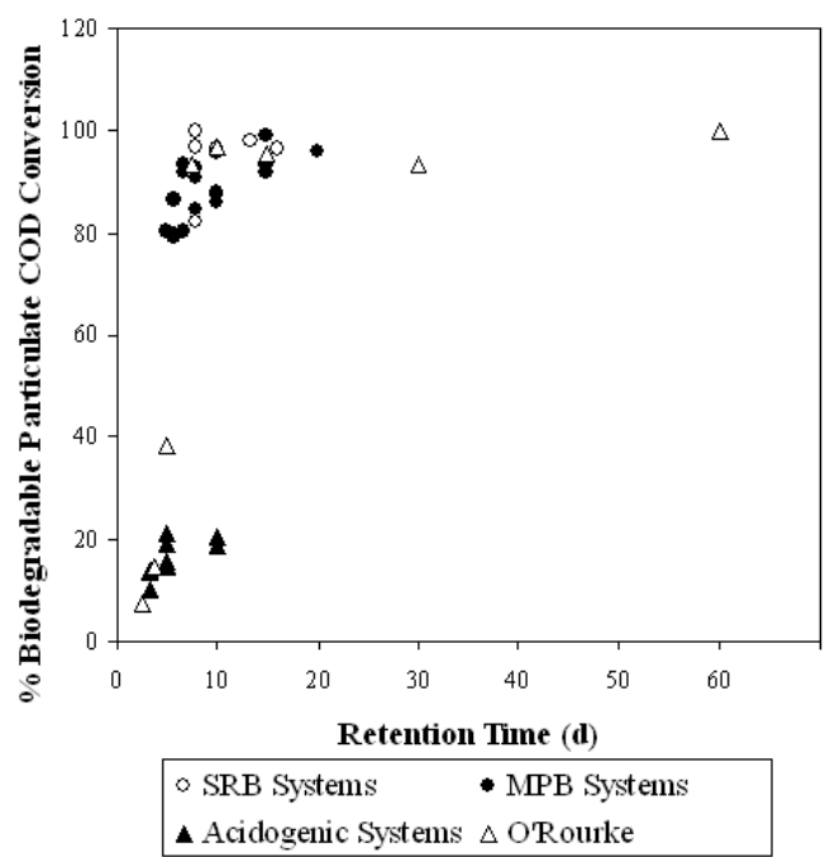

Figure 8

Biodegradable particulate COD conversions (as a percentage of influent primary sewage sludge biodegradable particulate chemical oxygen demand) versus retention time, for the methanogenic, acidogenic and sulphate-reducing systems reported by Ristow et al. (2009), and compared to the systems operated by O'Rourke (1968) (from Ristow et al., 2009)

$\mathrm{pH}$ values. Completely mixed methanogenic anaerobic digesters were operated at hydraulic retention times (= sludge retention time) from 5 to $60 \mathrm{~d}$, with feed COD concentrations of 2 , $9,13,25$ and $40 \mathrm{~g} \mathrm{COD} / \ell$, at a controlled temperature of $35^{\circ} \mathrm{C}$. Acidogenic systems were operated under varying hydraulic retention times $(3.33 ; 10 \mathrm{~d})$ and feed COD concentrations $(2-40 \mathrm{~g} \mathrm{COD} / \ell)$, at a constant temperature of $35^{\circ} \mathrm{C}$.

Sulphidogenic systems were operated at HRT varying from 6 to 47 days, sulphate concentrations from 1 to $9 \mathrm{~g} / \ell$ and feed COD concentrations of $1-26 \mathrm{~g} / \ell$.

Based on the results of these studies, Ristow et al. (2009) reported that under the conditions in which the sulphatereducing experimental systems were operated (sulphide not inhibitory), compared with the equivalent methanogenic systems, sulphate reduction was not found to influence the rate of PSS hydrolysis. However, as for the methanogenic systems, the presence of sulphate reduction significantly increased the rate of PSS hydrolysis when compared with acidogenic conditions (Fig. 8). This was a particularly important outcome of this investigation given the in vitro enzymological studies reported above in which sulphidogenesis was reported to enhance PSS hydrolysis. While the reports of the enzymology studies did not clearly specify whether their control systems were subject to primarily acidogenic rather than methanogenic conditions of operation, it is probable that this was the case. Further work is required to reconcile these findings and would be especially important where organic substrates more refractory to degradation than PSS, such as tannery and abattoir wastes, are used as electron donor/carbon sources in the process, and where operating conditions more robust than those normally required by methanogenic systems are applied.

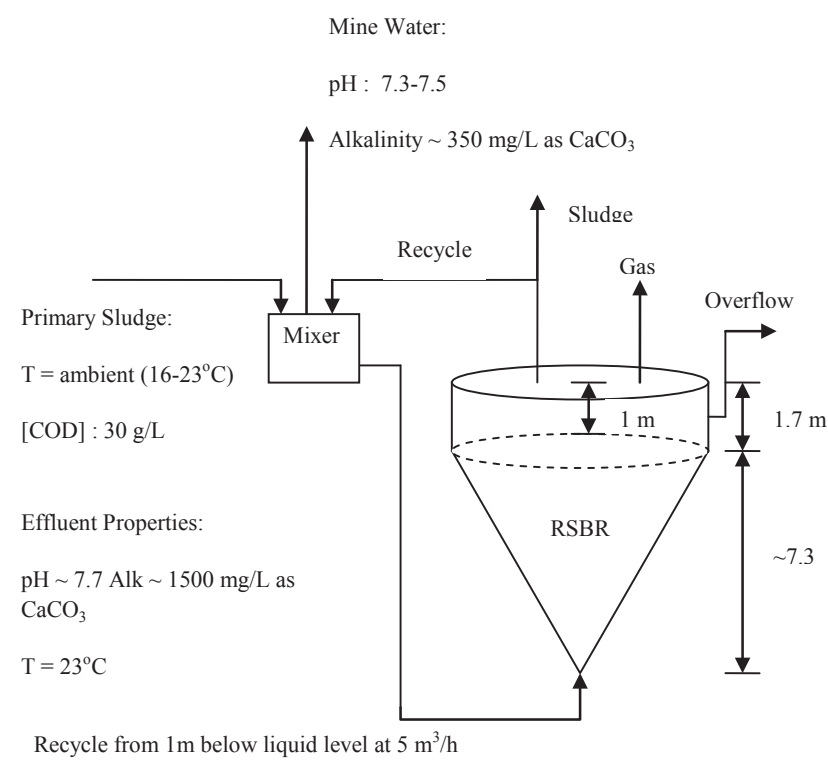

Sludge bed maintained at $\pm 0.5 \mathrm{~m}$ below liquid level

Overflow is practically free of suspended solids

Figure 9

Configuration and operating data for the Rhodes BioSURE pilot plant reactor at Erwat Ancor sewage treatment works (from Ristow et al., 2009)

Ristow (1999) and Ristow et al. (2002) had undertaken the mathematical modelling of the BioSURE pilot plant reactor at Grootvlei Gold Mine using the AQUASIM computational platform, and experience in modelling non-sulphate-reducing anaerobic digestion processes, also using AQUASIM, was reported by Van Rensburg et al. (2003) and Sötemann et al. (2005a,b). Using this background, mathematical modelling of PSS utilisation in the sulphate reduction process was modelled using both the AQUASIM and the WEST computational platforms and this joint research effort by the University of Cape Town Civil Engineering Department and the University of KwaZulu-Natal Pollution Research Group has been detailed by Ristow et al. (2009).

The WEST model was then adapted to represent the upflow reactor configuration, with retention and recycling of the sludge bed, as used in the technical-scale studies at the Ancor sewage treatment works. The process operating data used in the WEST modelling exercise are summarised in Fig. 9 (from Ristow et al., 2009).

The configuration diagram used in the WEST modelling study is shown in Fig. 10 and results for the simulated relationship between sulphate removal and COD utilisation are shown in Fig. 11. These results conformed quite closely to operational experience acquired in the technical-scale plant, and the WEST model was able to predict the COD load at which methanogenesis would commence under specific operating conditions. Reducing the COD:sulphate ratio needed to take into account the effect on sulphate reduction throughput achieved in the process and again the model was useful in predicting the optimum cut-off for setting the feed ratio under practical operating conditions. In addition to aiding the design, operation and control of the biological sulphate reduction unit process, the WEST model also provided a research and process evaluation tool targeting the optimisation of the system's performance (Ristow et al., 2009). 


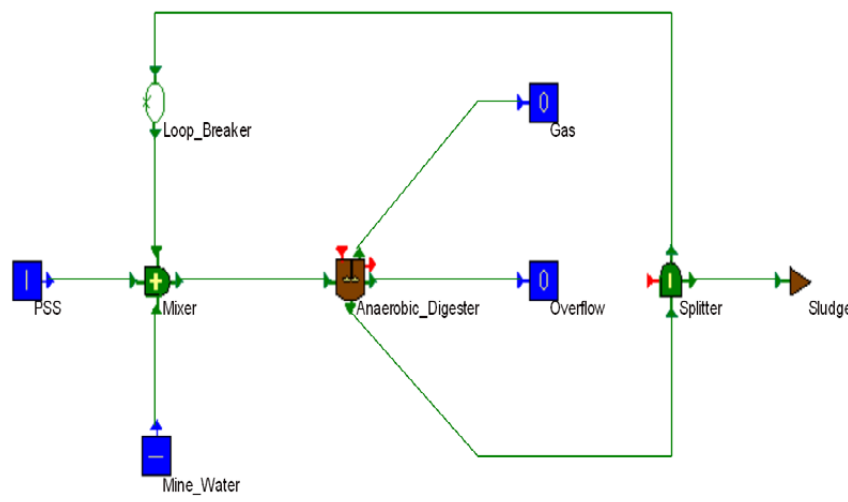

Figure 10

Configuration of the Rhodes BiOSURE pilot plant pilot plant reactor model used in the WEST simulation exercise (from Ristow et al., 2009)

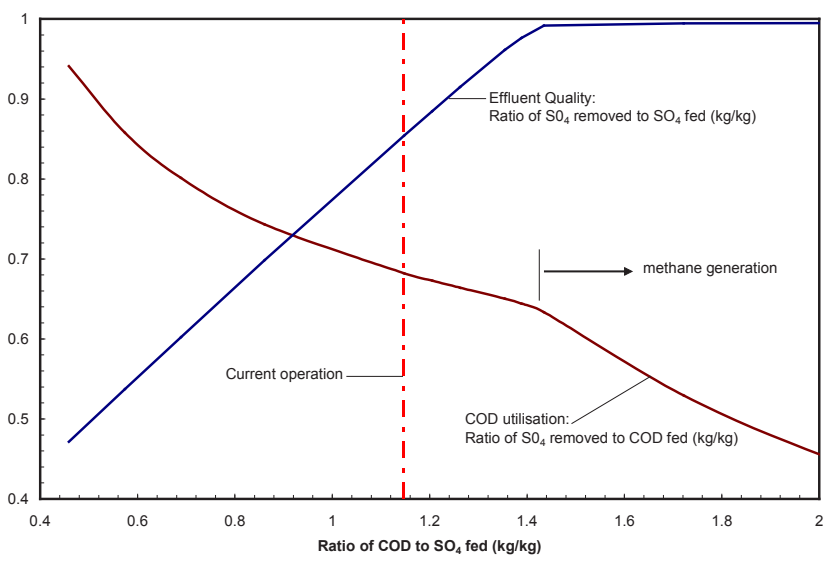

Figure 11

Simulated sulphate removal and COD utilisation ratios for varying sludge feed rates as simulated by the WEST computational programme (from Ristow et al., 2009)

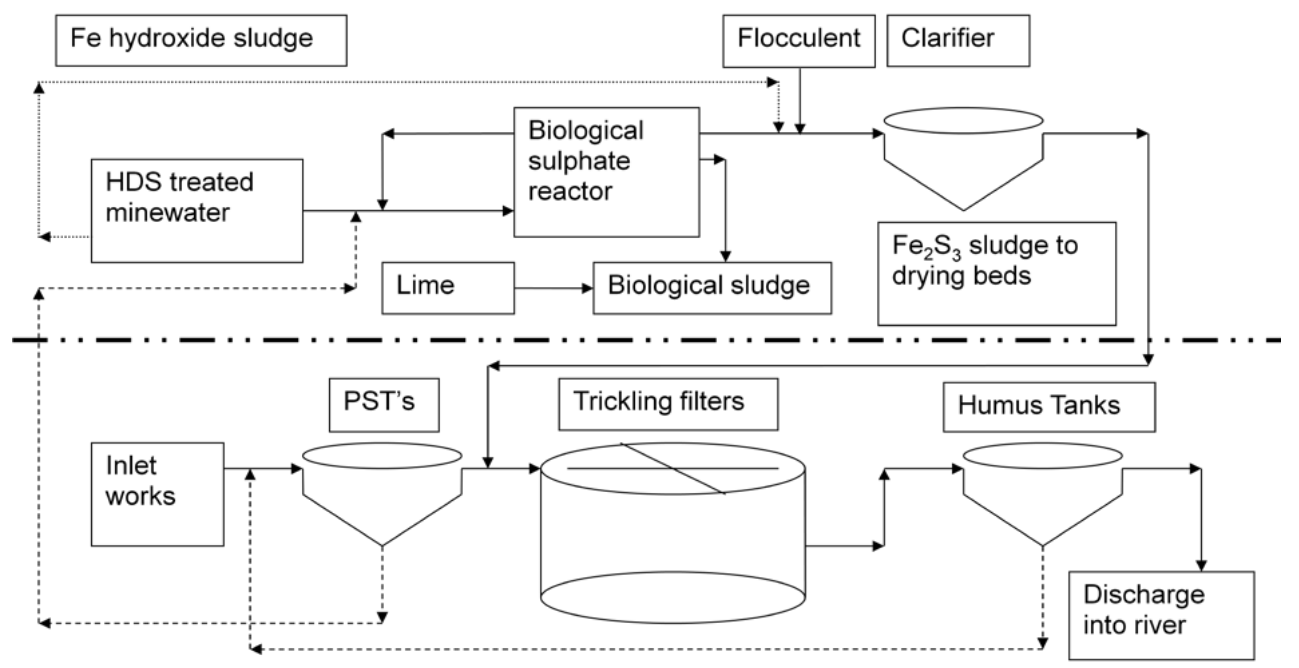

Figure 12

Process flow path of the Rhodes BioSURE Process full-scale 10 $\mathrm{Ml} /$ day plant constructed at the ERWAT Ancor sewage treatment works (from Joubert et al., 2012)

Primary sewage sludge

\section{FULL-SCALE PROCESS OPERATION}

Based on the positive results achieved in the technical-scale study in the URSBR, and with a degree of confidence in the availability of the WEST model as a process evaluation tool, a full-scale plant was designed to treat $10 \mathrm{M} \ell / \mathrm{d}$ of mine water from the Grootvlei Gold Mine (Neba et al., 2007; Joubert et al., 2012)

In the pilot and technical-scale studies only the performance of the sulphate reduction reactor (URSBR), which forms the core unit operation of the Rhodes BioSURE Process, was investigated. The requirement for the removal of metals from the AMD stream had been addressed in these investigations with the use of the ready supply of HDS treated waters from the Grootvlei Gold Mine. However, for full-scale application of the process a requirement remained for the removal of sulphide from the treated mine water stream in order to linearise operation of the biological sulphur cycle.

In the HDS process, ferrous iron is oxidised with the precipitation of a ferric hydroxide sludge. Polymers are added to aid flocculation and in the HDS operation at the Grootvlei Gold Mine this sludge had been disposed to a slimes dam. Enongene (2003b) and Joubert et al. (2012) investigated the use of this sludge for the removal of sulphides with the formation of a precipitable metal sulphide complex. This contains a complex mixture of metal sulphides, with $\mathrm{FeS}_{2}$ predominating and $\mathrm{Fe}_{2} \mathrm{~S}_{3}$ formed over time. The demonstration and development of successful sulphide removal, based on a metal sulphide precipitation unit operation, enabled the final configuration of the process design for the full-scale implementation of the Rhodes BioSURE Process as outlined in Fig. 12 (from Joubert et al., 2012).

Construction of the full-scale plant (Fig. 13) commenced with the installation of two $2.5 \mathrm{~km}$ pipelines from the Grootvlei Gold Mine HDS plant to the ERWAT Ancor sewage treatment works. These provided for the pumping of $10 \mathrm{Ml} /$ day HDS treated AMD and, in a separate pipeline, 2 MQ/day of the iron hydroxide sludge. From the collection sump PSS was blended with the HDS treated mine water before being fed into 8 upflow sludge blanket reactors with external sludge recycle (URSBRs). Undigested sewage sludge from the Ancor sewage treatment works, containing PSS and humus sludge, was used as the electron donor/carbon source for the operation of the biological sulphate reduction reaction. The process was designed to remove sulphate to levels below $250 \mathrm{mg} / \ell$, with the removal of more than $12 \mathrm{t} /$ day of sulphate required. Sewage sludge was utilised at a rate of $0.85 \mathrm{mg}$ biodegradable COD $/ \mathrm{mg}$ sulphate reduced and, to ensure that a carbon feed of consistent 


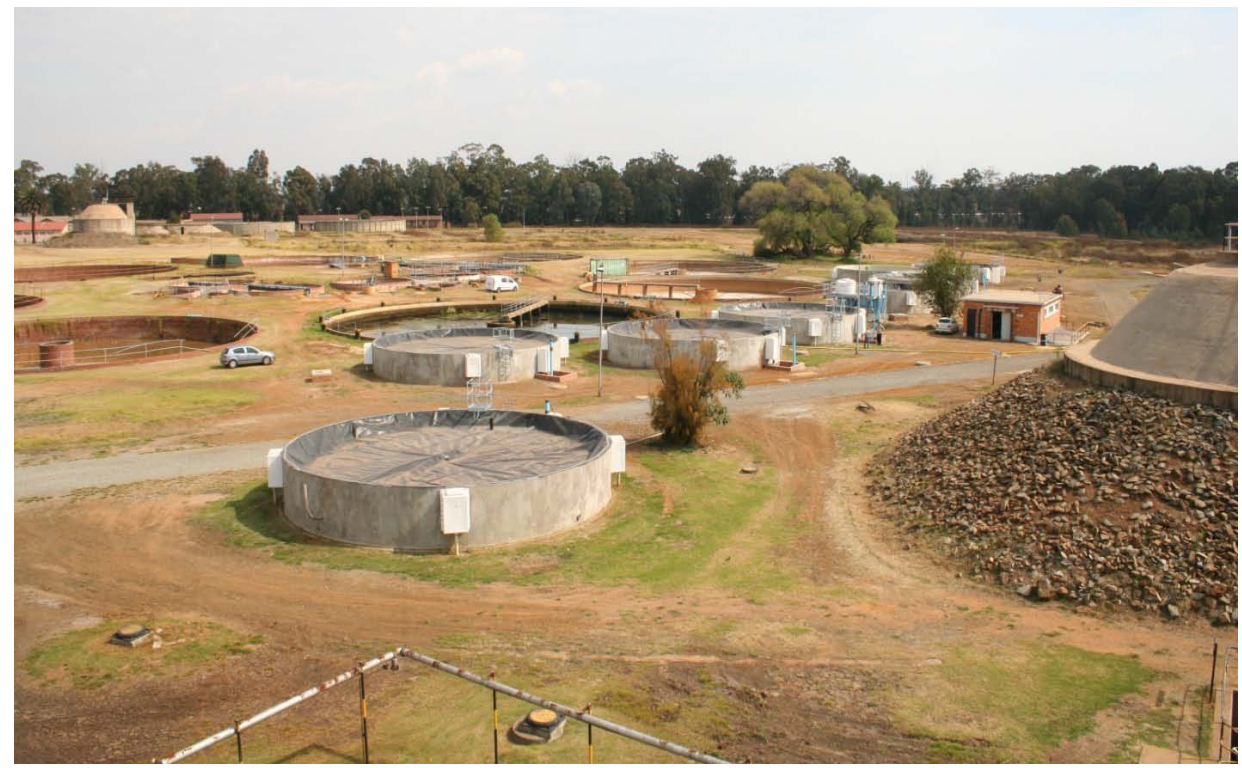

Figure 13

Photograph of the full-scale Rhodes BioSURE Process plant showing sealed upflow Recycling Sludge Bed Reactor modules, sulphide removal unit operation, mine water feed tanks, clarifiers and mine water balancing tank in the background (Neba et al., 2007)

concentration was applied, desludging of reactors was automated using a programmable logic controller (PLC) linked to actuated valves on each reactor (Joubert et al., 2012).

The sulphide-rich effluent from the reactors was collected in a covered sump, from where it was pumped to reactor-clarifiers for iron sulphide precipitation using the iron hydroxide sludge pumped from the HDS plant. The hydrogen sulphide in solution reacted with the iron slurry to form ferric sulphide which settled in the clarifier, and from where it was discharged to drying beds. A polyacrylamide solution was added to improve flocculation and settling in the reactor-clarifiers. The treated effluent was pumped to the biofilters of the existing sewage plant to remove any residual organic material and ammonia nitrogen, before being discharged. Lime was added to the waste biological sludge to reduce odour emissions before being applied to land (Joubert et al., 2012).

\section{PROCESS SUSTAINABILITY AND CONCLUSIONS}

Neba (2006) investigated factors influencing technology decision making relating to sustainable development needs in AMD management, and developed a decision support tool for assisting this process. The positioning of the Rhodes BioSURE Process with respect to environmental, technical, financial and social sustainability audit criteria has been summarised by Neba et al. (2007) as follows:

Environmental sustainability requirements addressed in the AMD treatment operation include the removal of sulphate salinity in large-volume AMD treatment applications and codisposal of PSS. The benefits relate principally to environmental health of aquatic systems and water supply in an extremely water-scarce area. Potential problems include effective final disposal for the metal/sulphide complex wastes generated in the treatment operation. Sulphide gas generated in the process is potentially hazardous and needs careful monitoring and control.

Long-term technical sustainability is available by utilising well-understood water treatment technical infrastructure and placing the treatment function in the hands of the public utility operator. The availability of sewage sludge presents a potential constraint to the implementation of the process where 850 $\mathrm{kg}$ biodegradable COD is required per ton sulphate removed.
Where mine waters are generated close to large conurbations, such as is the case in the Witwatersrand area, large volumes of PSS will be available. However, where the volumes of AMD requiring treatment exceed PSS availability, or where PSS is not available, additional sources of complex organic carbon wastes may be required. In this regard algal biomass, tannery, abattoir and dairy wastes have been successfully evaluated (Boshoff et al., 2004a,b; Van Hille et al., 1999a,b; Joubert et al., 2012).

Financial sustainability relates to cost-benefit calculations, including the charge raised to the treatment function, the value of treated water and the cost saving in sewage sludge co-disposal. Processing of other sources of organic wastes offers another area of potential value recovery against costs of disposal to landfill. Provisional cost-benefit estimates in the comparison of the Rhodes BioSURE Process with other competitive processes were undertaken by Van der Merwe and Lea (2003), and, although favourable, have not yet been reported in the public domain for the full-scale process operation.

Social sustainability requirements relate to, among other issues, reduced economic activity, joblessness and impoverishment following mine closure. Kumalo (2005) reported an applied anthropology study on the potential of irrigated urban agricultural projects to relieve poverty in informal settlement communities. An interdisciplinary study on the use of treated AMD in high-value crop irrigated agriculture for job creation was reported by Rose et al. (2009).

\section{ACKNOWLEDGEMENTS}

The author acknowledges Rhodes University for support in the preparation of this review, the Water Research Commission, ERWAT Water Care Company Company and BioPAD who financed the research and development programme over many years.

\section{REFERENCES}

BELL F G, BULLOCK SET, HÄLBICH TFJ and LINDSAY P (2001) Environmental impacts associated with an abandoned mine in the Witbank Coalfield, South Africa. Int. J. Coal Geol. 45 195-216. BLOWES DW, PTACEK CJ, JAMBOR JL and WEISENER CG (2003) The geochemistry of acid mine drainage. In: Holland HD and Turekian KK (eds.) Treatise on Geochemistry. Elsevier, Oxford. 
$150-204$.

BOSHOFF G (1999) Algal metal binding by waste grown algae. PhD thesis, Rhodes University.

BOSHOFF G, DUNCAN J and ROSE PD (1996) An algal-bacterial integrated ponding system for the treatment of mine drainage waters. J. Appl. Phycol. 8442.

BOSHOFF G, DUNCAN J and ROSE PD (2004a) Tannery effluent as a carbon source for biological sulphate reduction. Water Res. 38 (11) 2651-2658.

BOSHOFF G, DUNCAN J and ROSE PD (2004b) The use of microalgal biomass as a carbon source for biological sulphate reducing systems. Water Res. 38 (11) 2659-66.

CHAUKE G (2002) The molecular microbial ecology of sulphate reduction in the Rhodes BioSURE process. MSc thesis, Rhodes University.

CORBETT C (2001) Development of the Rhodes BioSURE Process in the treatment of acid mine drainage wastewaters. MSc thesis, Rhodes University.

DUNN K (1998) The biotechnology of high rate algal ponding systems in the treatment of saline tannery wastewaters. PhD thesis, Rhodes University.

ENONGENE G (2003a) The enzymology of enhanced hydrolysis within the biosulphidogenic recycling sludge bed reactor. $\mathrm{PhD}$ thesis, Rhodes University.

ENONGENE G (2003b) A novel method for the precipitation of ferrous iron and the removal of sulfide from the Rhodes BioSURE effluents. Internal Report, Environmental Biotechnology Research Unit, Rhodes University.

EWART TI (2011) Acid mine drainage in the Gauteng Province of South Africa: a phenomenological study on the degree of alignment between stakeholders concerning a sustainable solution to acid mine drainage. MPhil thesis, Stellenbosch University.

FIELDS S (2003) The earth's open wounds: Abandoned and orphaned mines. Environ. Health Perspect. 111 154-161.

HARTNADY CJH (2009) South Africa's gold production and reserves. S. Afr. J. Sci. $1059-10$

HODGSON FDI, USHER BH, SCOTT R, ZEELIE S, CRUYWAGEN I and DE NECKER E (2001) Prediction techniques and preventative measures relating to the post-operational impact of underground mines on the quality and quantity of groundwater resources. WRC Report No. 699/1/01. Water Research Commission, Pretoria.

INTER-MINISTERIAL COMMITTEE (2010) Mine water management in the Witwatersrand Gold Fields with special emphasis on acid mine drainage. Report to the Inter-Ministerial Committee on Acid Mine Drainage. Department of Water Affairs, Pretoria.

JOHNSON DB (2003) Chemical and microbiological characteristics of mineral spoils and drainage waters at abandoned coal and metal mines. Water Air Soil Pollut. 3 (1) 47-66.

JOHNSON DB and HALLBERG KB (2005) Acid mine drainage remediation options: a review. Sci. Total Environ. 338 3-14.

JOUBERT H, POCOCK G, WILKEN K and GODONGWANA Z (2012) Full-scale implementation of the Rhodes BioSURE Process. Interim report for WRC Project No. K5/1780, March 2012. Water Research Commission, Pretoria.

KUMALO S (2005) The rural-urban interface: The ambiguous nature of informal settlements, with special reference to the Daggafontein settlement in Gauteng. MA thesis, Rhodes University.

LEBLANC M, MORALES JA, BORREGO J and ELBAZ-POULICHET $\mathrm{F}(2000)$ 4,500-year-old mining pollution in southwestern Spain: long-term implications for modern mining pollution. Econ. Geol. 95 655-662.

LIN L and HANSEN RN (2010) Mine flooding, identification of decant site and determination of environmental critical level on the Central Rand Gold Field. Council for Geoscience Report No. 20100199. Council for Geoscience, Pretoria.

LOTTERMOSER BG (2010) Mine Wastes: Characterization, Treatment and Environmental Impacts. Springer, Berlin.

MACK CL, RAJA SA, PULLES WB, MUHLBAUER RC and HEATH RA (2009) Application of the linear flow channel reactor (LFCR) for the removal of sulphide from semi-treated acid mine drainage (AMD). Abstracts of the International Mine Water Conference,
19-23 October 2009, Pretoria.

McCARTHY TS (2010) The decant of acid mine water in the Gauteng city-region - analysis, prognosis and solutions. Provocations Series, Gauteng City-Region Observatory. Universities of the Witwatersrand and Johannesburg, Johannesburg.

McCARTHY (2011) The impact of acid mine drainage in South Africa S. Afr. J. Sci. 107 5-6.

MOLEPANE NP (1999) Biological sulphate reduction utilizing hydrolysis of a complex carbon source. MSc thesis, Rhodes University.

MOLWANTWA J (2002) The enhanced hydrolysis of sewage sludge in sulphidogenic environments. MSc thesis, Rhodes University.

MOLWANTWA J (2008) Floating sulphur biofilms: structure, function and biotechnology. PhD thesis, Rhodes University.

MOLWANTWA JB, BOWKER M, GILFILLAN J, REIN N, DORRINGTON R, HART OO and ROSE PD (2007) Investigation and development of the biotechnology of the floating sulphur biofilm in the beneficiation and treatment of wastewater. WRC Report No. K5/1454. Water Research Commission, Pretoria.

MOLWANTWA JB, COETSER SE, HEATH R and ROSE PD (2007). Development of the floating sulphur biofilm reactor for sulphide oxidation in biological water treatment systems. Water SA 30 (5) 655-657.

NAIKER K, CUKROWSKA E and McCARTHY TS (2003) Acid mine drainage arising from gold mining activity in Johannesburg, South Africa, and environs. Environ. Pollut. 122 29-40.

NEBA A (2006) The Rhodes Biosure Process and the use of sustainability indicators in the development of biological mine water treatment. PhD thesis, Rhodes University.

NEBA A, WHITTINGTON-JONES K and ROSE PD (2007) The Rhodes BioSURE Process: Process scale-up in the treatment of mine drainage wastewaters and the disposal of sewage sludge. WRC Report No. TT 198/07, Water Research Commission, Pretoria.

O'ROURKE JT (1968) Kinetics of anaerobic treatment at reduced temperatures. PhD dissertation, Department of Civil Engineering, Stanford University.

OSWALD WJ (1988) Large-scale algal systems (engineering aspects). In: Borowitzka MA and Borowitzka LJ (eds.) Microalgal Biotechnology. Cambridge University Press, Cambridge.

PLETSCHKE BI, ROSE PD and WHITELY CG (2002) The enzymology of sludge solubilisation utilising sulphate reducing systems: Identification and properties of ATP-sulphurylases. Enzyme Microb. Technol. 31 329-336.

RISTOW NE (1999) The modelling of the falling sludge bed reactor using AQUASIM. MSc thesis, University of Cape Town.

RISTOW NE (2004) Hydrolosis of primary sewage sludge under methanogenic, acidogenic and sulfidogenic conditions. $\mathrm{PhD}$ thesis, University of Cape Town.

RISTOW NE, WHITTINGTON-JONES K, CORBETT C, ROSE P and HANSFORD GS (2002) Modelling of a recycling sludge bed reactor using AQUASIM. Water SA 28 (1) 111-120.

RISTOW NE, SÖTEMANN SW, LOEWENTHAL RE, WENTZEL, MC and EKAMA GA (2004) Hydrolysis of primary sludge under methanogenic, acidogenic and sulphate-reducing conditions. WRC Report No. 1216/1/04. Water Research Commission, Pretoria.

RISTOW NE, SÖTEMANN SW, RAJKUMAR S, WENTZEL MC, BROUCKAERT CJ, BUCKLEY CA, EKAMA GA and ROSE PD (2009) Biotechnology of saline and sewage wastewater cotreatment. Volume 1: Integrated physical, chemical and biological process kinetic models for anaerobic digestion of primary sewage sludge. WRC Report No. TT 393/09. Water Research Commission, Pretoria.

ROSE PD (1992) A biotechnological approach to the removal of organ ics from saline effluents. WRC Report No. K5/410. Water Research Commission, Pretoria.

ROSE PD, MAART BA, DUNN KM, ROWSWELL RA and BRITZ P (1996) High rate oxidation ponding for the treatment of tannery effluents. Water Sci. Technol. 33 219-227.

ROSE PD, BOSHOFF GA, VAN HILLE RP, WALLACE LMC, DUNN KM and DUNCAN JR (1998) An integrated algal sulphate reducing high rate ponding process for the treatment of acid mine drainage 
wastewaters. Biodegradation 9 247-257.

ROSE PD, DUNCAN JR, VAN HILLE RP and BOSHOFF GA (1999) Use of ponds to treat sulphate solutions and ASPAM process. Patents: RSA 99/4585; USA 6,315,904.

ROSE PD and HART OO (1999a) Treatment of water-modification. Patent: RSA 99/6546; Australia 759,811; Namibia 99/0057; USA $6,228,263$.

ROSE PD and HART OO (1999b) Treatment of sulphate containing metaliferous wastewater. Patent: RSA 99/4584; USA 6,197,196.

ROSE PD and HART OO (2001) Treatment of sewage. Patent: RSA 2001/3017; Australia 751,562; USA 6,521,128; EPO 1124763 (Belgium 1124763; France 1124763; Germany 1124763; Ireland 1124763; Italy 1124763; Netherlands 1124763; Spain 1124763; Sweden 1124763; UK 1124763).

ROSE PD (2002) Salinity, sanitation and sustainability: A study in environmental biotechnology and integrated wastewater beneficiation in South Africa. Volume 1: Overview. WRC Report No. TT 187/02, Water Research Commission, Pretoria.

ROSE PD, BOSHOFF GE and MOLIPANE NP (2002) Salinity, sanitation and sustainability: A study in environmental biotechnology and integrated wastewater beneficiation in South Africa. Volume 1: Integrated algal ponding systems and the treatment of domestic and industrial wastewater. Part 3: Mine drainage wastewater: The ASPAM MODEL. WRC Report No. TT 192/02. Water Research Commission, Pretoria.

ROSE PD, CORBETT CJ, WHITTINGTON-JONES K and HART OO (2004) The Rhodes BioSURE Process. Part 1: Biodesalination of mine drainage wastewaters. WRC Report No. TT 195/04, Water Research Commission, Pretoria.

ROSE PD, MOFFETT M, PULLES W, NELL JP, LOUW D, MELVILLE A, LEUCONA A, KUMALO S and DE WET C (2009) Biotechnology of saline and sewage wastewater co-treatment Volume 2. Integrated beneficiation of mine wastewaters, mine drainage wastewater treatment and planning for the social and labour component in sustainable mine operation and closure: Case study for a spatial development initiative in Eastern Ekurhuleni. WRC Report No. TT 409/09, Water Research Commission, Pretoria.

SCOTT R (1995) Flooding of Central and East Rand gold mines: An investigation into controls over the inflow rate, water quality and the predicted impacts of flooded mines. WRC Report No. 486/1/95, Water Research Commission, Pretoria, South Africa.

SEGEZZO L (2004) Anaerobic treatment of domestic wastewater in subtropical regions. $\mathrm{PhD}$ thesis, Wageningen University.

SÖTEMANN SW, VAN RENSBERG P, RISTOW NE, WENTZEL MC, LOEWENTHAL RE and EKAMA GA (2005a) Integrated chemi$\mathrm{cal} /$ physical and biological processes modelling Part2 - Anaerobic digestion of sewage sludges. Water $S A 31$ (4) 545-568.

SÖTEMANN SW, RISTOW NE, WENTZEL MC and EKAMA GA (2005b) A steady state model for anaerobic digestion of sewage sludges. Water SA 31 (4) 511-528.

TANDLICH R (2012) Bioremediation challenges originating from mining and related activities in South Africa. J. Bioremediation Biodegradion 33.

TURTON A (2004) Gold, scorched earth and water: The hydropolitics of development in Johannesburg. Water Management in Megacities. Stockholm Water Symposium, 15 August 2004.
TUTU H, MCCARTHY TS, CUKROWSKA E (2008) The chemical characteristics of acid mine drainage with particular reference to sources, distribution and remediation: The Witwatersrand Basin, South Africa, as a case study. Appl. Geochem. 23 3666-3684.

VAN DER MERWE W and LEA I (2003) Towards sustainable mine water treatment at Grootvlei Mine (2003). Proc. $8^{\text {th }}$ International Congress on Mine Water and the Environment, 19-22 October 2003, Johannesburg, South Africa.

VAN GEEN A, ADKINS JF, BOYLE EA, NELSON CH and PALANQUES A (1997) A 120-yr record of widespread contamination from mining of the Iberian pyrite belt. Geology 25 (4) 291-294.

VAN HILLE R, BOSHOFF G, ROSE P and DUNCAN J (1999a) A continuous process for the biological treatment of heavy metal contaminated acid mine water. Resour. Conserv. Recy. 27 157-167.

VAN HILLE RP, BOSHOFF GA, ROSE PD and DUNCAN JR (1999b) A continuous process for the biological treatment of heavy metal contaminated acid mine drainage water. Patent: RSA 99/4586; USA $6,203,904$.

VAN HILLE RP, VAN WYK N, MOTLELENG L and MOORUTH N (2011) Lessons in passive treatment: Towards efficient operation of a sulphate reduction - sulphide oxidation system. Abstracts of the International Mine Water Conference, 4-11 September 2011, Aachen, Germany.

VAN RENSBURG P, MUSVOTO EV, WENTZEL MC and EKAMA GA (2003) Modelling multiple mineral precipitation in anaerobic digester liquor. Water Res. 37 (13) 3087-3097.

WATSON SD, AKHURST T, WHITELEY CG, ROSE PD and PLETSCHKE BI (2004) Primary sludge floc degradation is accelerated under biosulphidogenic conditions: Enzymological aspects. Enzyme Microb. Technol. 34 (6) 595-602.

WHITELEY CG, HERON P, PLETSCHKE B, ROSE PD, TSHIVHUNGE S, VAN JAARSVELD FP and WHITTINGTON-JONES K (2002a) The enzymology of sludge solubilisation utilising sulphate reducing systems. Properties of proteases and phosphatases. Enzyme Microb. Technol. 31 (4) 419-424.

WHITELEY CG, ROSE P, PLETSCHKE B and MELAMANE X (2002b) Enzymology of accelerated sludge solubilisation: Properties of lipases. Water Res. 37 (2) 289-296.

WHITELEY CG, PLETSCHKE B, ROSE P and NGESI N (2002c) Specific sulphur metabolites stimulate $\beta$-glucosidase activity in an anaerobic sulphidogenic bioreactor. Biotechnol. Lett. 24 1509-1513.

WHITELEY CG, BURGESS JE, MELAMANE X, PLETSCHKE B and ROSE PD (2003) The enzymology of sludge solubilisation utilising sulphate-reducing systems: the properties of lipases. Water Res. 37 289-296.

WHITTINGTON-JONES K (2000) Sulpide-enhanced hydrolysis of primary sewage sludge: implications for the bioremediation of sulphate-enriched wastewaters. PhD thesis, Rhodes University.

WHITTINGTON-JONES KJ, CORBETT CJ and ROSE PD (2002) The Rhodes BioSURE Process. Part 2: Enhanced hydrolysis of organic carbon substrates - development of the recycling sludge bed reactor. WRC Report No. TT 196/02, Water Research Commission, Pretoria.

WHITTINGTON-JONES KJ, MOLWANTWA JB and ROSE PD (2006) Enhanced hydrolysis of carbohydrates in primary sludge under biosulfidogenic conditions. Water Res. 40 (8) 1577-1582.

YOUNGER PL (1997) The longevity of mine water pollution: a basis for decision-making. Sci. Total Environ. 194-195 45-466. 